\title{
Predicting Accumulation of Intermediate Compounds in Nitrification and Autotrophic Denitrification Processes: A Chemical Approach
}

\author{
José Luis Campos (D, ${ }^{1}$ Jacques Dumais, ${ }^{1}$ Juan Pablo Pavissich, ${ }^{1,2}$ Oscar Franchi, \\ Dafne Crutchik, ${ }^{1}$ Marisol Belmonte $\mathbb{D}^{\mathrm{D}},{ }^{3}$ Martín Faúndez, ${ }^{4}$ \\ Lorena Jorquera, ${ }^{5}$ Alba Pedrouso ${ }^{D},{ }^{6}$ Anuska Mosquera-Corral, ${ }^{6}$ and Ángeles Val del Río ${ }^{6}$ \\ ${ }^{1}$ Facultad de Ingeniería y Ciencias, Universidad Adolfo Ibáñez, Avda. Padre Hurtado 750, Viña del Mar, Chile \\ ${ }^{2}$ Center of Applied Ecology and Sustainability (CAPES), Santiago, Chile \\ ${ }^{3}$ Department of Environment, Faculty of Engineering, University of Playa Ancha, Avenida Leopoldo Carvallo 270, \\ 2340000 Valparaíso, Chile \\ ${ }^{4}$ Chemical and Environmental Engineering Department, Technical University Federico Santa María, \\ Ave. España 1680, Valparaíso, Chile \\ ${ }^{5}$ Escuela de Ingeniería en Construcción, Facultad de Ingeniería, Pontificia Universidad Católica de Valparaíso, \\ Avenida Brasil 2147, Valparaíso, Chile \\ ${ }^{6}$ Department of Chemical Engineering, Institute of Technology, Universidade de Santiago de Compostela, \\ E-15705 Santiago de Compostela, Spain
}

Correspondence should be addressed to José Luis Campos; jluis.campos@uai.cl

Received 16 January 2019; Revised 26 May 2019; Accepted 24 June 2019; Published 7 July 2019

Academic Editor: Raf Dewil

Copyright (C) 2019 José Luis Campos et al. This is an open access article distributed under the Creative Commons Attribution License, which permits unrestricted use, distribution, and reproduction in any medium, provided the original work is properly cited.

Nitrification and sulfur-based autotrophic denitrification processes can be used to remove ammonia from wastewater in an economical way. However, under certain operational conditions, these processes accumulate intermediate compounds, such as elemental sulphur, nitrite, and nitrous oxide, that are noxious for the environment. In order to predict the generation of these compounds, an analysis based on the Gibbs free energy of the possible reactions and on the oxidative capacity of the bulk liquid was done on case study systems. Results indicate that the Gibbs free energy is not a useful parameter to predict the generation of intermediate products in nitrification and autotrophic denitrification processes. Nevertheless, we show that the specific productions of nitrous oxide during nitrification, and of elemental sulphur and nitrite during autotrophic denitrification, are well related to the oxidative capacity of the bulk liquid.

\section{Introduction}

Removal of reduced nitrogen species from wastewater is conventionally carried out by means of nitrification and denitrification biological processes, where ammonia nitrogen $\left(\mathrm{NH}_{4}{ }^{+}\right)$is first converted to nitrate $\left(\mathrm{NO}_{3}{ }^{-}\right)$and then to nitrogen gas $\left(\mathrm{N}_{2}\right)$ [1]. Wastewater nitrification occurs under aerobic conditions whereas denitrification is anaerobic. Nitrification is conducted in two consecutive steps by nitrifying microorganisms: ammonia conversion into nitrite by ammonia oxidizers (i.e., partial nitrification) and then nitrite conversion into nitrate by nitrite oxidizers. The most studied nitrifiers are ammonia-oxidizing bacteria (AOB), such as Nitrosomonas, and nitrite-oxidizing bacteria (NOB), where Nitrobacter is the most referenced genus. Nitrifiers are chemolithotrophic and their activity decreases as the $\mathrm{pH}$ is reduced below neutrality [2].

Typically, denitrification relies on the oxidation of organic carbon by heterotrophic bacteria, and readily biodegradable carbon sources such as methanol, ethanol, and acetate, 
must be added externally to treatment plants [3]. Organic electron donors are expensive and have high biomass yields, leading to higher operational costs and sludge production [4]. Autotrophic denitrification is an alternative process for the reduction of nitrate or nitrite $\left(\mathrm{NO}_{2}{ }^{-}\right)$, which is accomplished by oxidation of inorganic electron donors, including different forms of sulfur such as sulphide [5]. Among denitrifying bacteria that are able to use sulfur compounds as electron donors is Thiobacillus denitrificans which is the most studied. This species of bacteria has its optimal growth conditions at $\mathrm{pH}$ 7.5-8.0 [6]. Autotrophic denitrification supported by sulfur poses several advantages over common denitrification, because sulfur compounds are more cost-effective and have much lower sludge production [7]. Thus, the combination of nitrification and sulfur-based denitrification is attracting increasing interest in recent years. Particularly, these processes are gaining attention in order to remove nitrogen from anaerobic reactor effluents containing low organic matter and high ammonia and sulphide $\left(\mathrm{S}^{2-}\right)$ concentrations [7]. However, under certain operational conditions ammonia and sulphide removal processes generate undesirable intermediates such as nitrous oxide $\left(\mathrm{N}_{2} \mathrm{O}\right)$, nitrite, and elemental sulphur $\left(\mathrm{S}^{0}\right)$. Nitrous oxide is a potent greenhouse gas, which can be produced in the aerobic nitrification process by $\mathrm{AOB}$ in presence of low dissolved oxygen (DO) concentrations and nitrite accumulation [8]. Under aerobic conditions, AOB metabolism can generate $\mathrm{N}_{2} \mathrm{O}$ through hydroxylamine oxidation or nitrite oxidation [8] while NOB are not able to produce this compound in presence of oxygen [9]. On the other hand, the accumulation of nitrite and elemental sulphur can occur during autotrophic denitrification [10]. The presence of these compounds should be avoided to maintain the stability of the process due to the toxic effect of nitrite on the sulphide oxidation rate [11] and the decrease of biomass activity due to the formation of sulphur precipitates [12]. The accumulation of both compounds could be related to the $\mathrm{S} / \mathrm{N}$ ratio of the influent $[13,14]$. $\mathrm{S} / \mathrm{N}$ ratio may have a major influence on the distribution of sulphide oxidation and nitrate reduction end-products and on their simultaneous removal $[10,15,16]$.

Under a thermodynamic point of view, the formation of redox intermediates could be predicted considering the Gibbs free energy $(\Delta G)$ of the potential reactions, normalized to the number of moles of electrons $\left(\mathrm{e}^{-}\right)$transferred in such reactions, since the most energetically favorable reactions would be preferentially used by microorganisms [18]. Alternatively, to predict the reactions that can take place in a specific aqueous system, Scott and Morgan [17] proposed the use of a conservative parameter called oxidative capacity (OXC) which represents the total number of transferable electrons in a given system. This parameter is defined as the equivalent sum of all oxidants that can be reduced with a strong reductant to an equivalence point. At every equivalence point a particular electron condition defines a reference level of electrons. By using the OXC concept, the information about the chemical composition of the bulk liquid is condensed into a single descriptive parameter which can be easily calculated as

$$
\text { OXC (equivalents/L) }=\Sigma \mathrm{n}_{\mathrm{i}} \cdot[\mathrm{Ox}]_{\mathrm{i}}-\Sigma \mathrm{n}_{\mathrm{i}} \cdot[\mathrm{Red}]_{\mathrm{i}}
$$

where $[\mathrm{Ox}]_{\mathrm{i}}$ and $[\mathrm{Red}]_{\mathrm{i}}$ represent the concentration (molar) of the individual oxidants and reductants of the system and $\mathrm{n}_{\mathrm{i}}$ is the number of equivalent electrons that are transferred.

The objective of this research is to determine if the Gibbs free energy or the oxidative capacity are useful parameters to predict the possible accumulation of intermediate compounds during nitrification and autotrophic denitrification processes.

\section{Materials and Methods}

2.1. Experimental Data. The production of intermediate compounds in nitrification and autotrophic denitrification processes was analyzed using data from experimental benchscale reactors. Measurements of $\mathrm{N}_{2} \mathrm{O}$ emissions in nitrification were those obtained by Campos et al. [9], during the operation of a nitrifying biofilm airlift suspended (BAS) reactor under different dissolved oxygen concentrations. The nitrifying BAS reactor was of $2.6 \mathrm{~L}$, continuously fed with a synthetic medium containing $500 \mathrm{mg} \mathrm{NH}_{4}{ }^{+}-\mathrm{N}$ per liter, operated at $23^{\circ} \mathrm{C}$ and a hydraulic retention time of $8 \mathrm{~h}$ under three different DO concentration conditions: 1, 2, and $5 \mathrm{mg} \mathrm{O}_{2}$ per liter. After 1 week of operation, once a constant composition of the liquid phase was achieved for each condition, quick changes (3-5 min in length) in the DO concentration were carried out (Table 1). DO concentrations tested in these quick-change assays were $0.5,1,2$, and $5 \mathrm{mg} \mathrm{O}_{2}$ per liter. Thus, a total of 12 conditions were evaluated for the production of $\mathrm{N}_{2} \mathrm{O}$ (Table 1). Periodical samples of the outlet gas were taken until verifying that a constant concentration of $\mathrm{N}_{2} \mathrm{O}$ was reached for each DO concentrationtested.

The accumulation of elemental sulfur and nitrite during autotrophic denitrification was studied using data from Fajardo et al. [12], for a denitrifying sequencing batch reactor (SBR) simultaneously removing nitrate and sulphide operated during 220 days. The SBR had a working volume of $1 \mathrm{~L}$ and was fed with a synthetic medium containing nitrate and sulphide (500 $\mathrm{mg} \mathrm{NO}_{3}{ }^{-}-\mathrm{N} / \mathrm{L}$ and 100-450 $\mathrm{mg} \mathrm{S}^{-2}$-S/L) using different loading rates in 9 stages (Table 1 ). The reactor was operated at $30^{\circ} \mathrm{C}$ and at a fixed hydraulic retention time of $1 \mathrm{~d}$.

2.2. Calculations. The reactions involved during the analyzed processes of ammonia oxidation and of autotrophic denitrification with sulphur compounds and related to the production of $\mathrm{NO}_{2}{ }^{-}, \mathrm{N}_{2} \mathrm{O}$, and $\mathrm{S}^{0}$ as intermediate compounds, are listed in Table 2. The Gibbs free energy value was calculated taking into account the concentrations of the different compounds for each operational condition, normalized to the number of moles of $\mathrm{e}^{-}$transferred in the reaction $\left(\Delta \mathrm{G} / \mathrm{e}^{-}\right)$.

To determine the oxidative capacity for the different operating conditions, first, in order to make a "redox ladder" [17], the redox potential of each half reaction involved in ammonia oxidation and autotrophic denitrification was calculated as a function of $\mathrm{pH}$ (Table 3), using the experimental data summarized in Table 1. Table 4 shows that, for both nitrification and denitrification, the related redox potential values were similar for all the operational stages. A "redox ladder" was set using the calculated potentials (Figure 1). In the case 


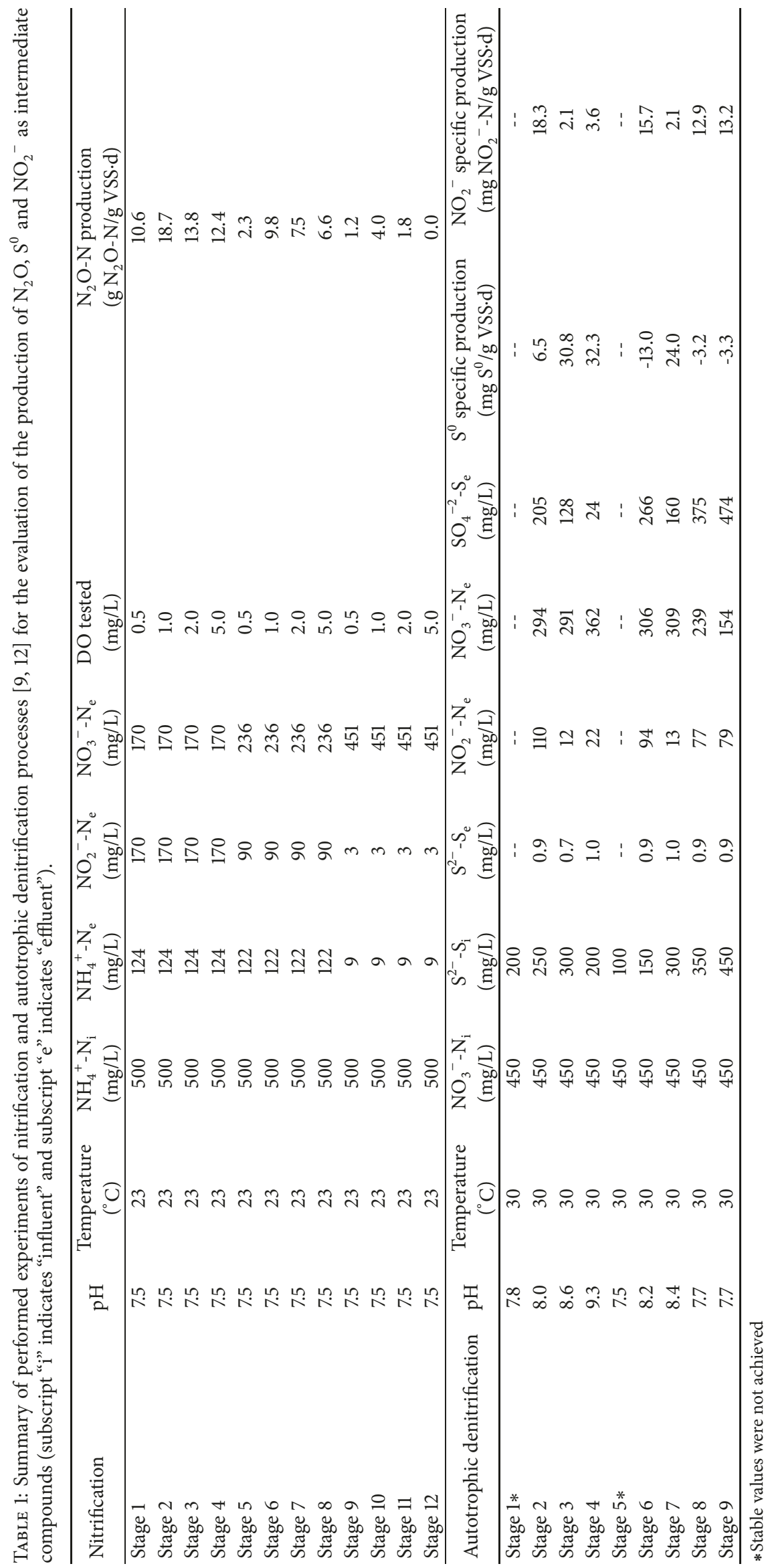


TABLE 2: Reactions involved during ammonia oxidation and autotrophic denitrification processes, number of $\mathrm{e}^{-}$transferred and $\Delta \mathrm{G}(\mathrm{kJ})$ for each reaction.

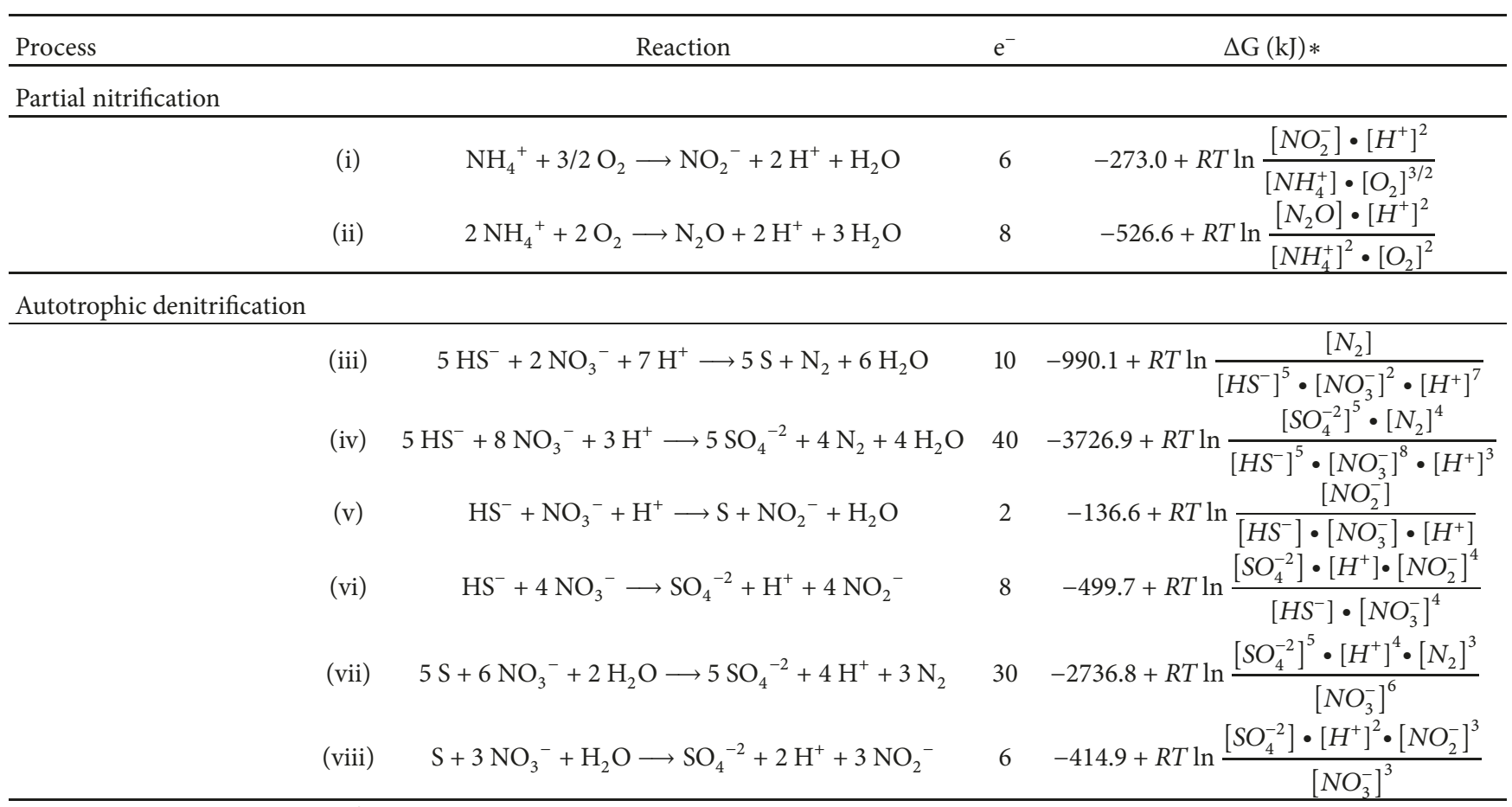

$* \mathrm{R}$ is the ideal gas constant $\left(8.31 \cdot 10^{-3} \mathrm{~kJ} / \mathrm{mol} \cdot \mathrm{K}\right) ; \mathrm{T}$ is the operational temperature $(\mathrm{K})$; concentrations are given as molar $(\mathrm{M})$.

TABLE 3: Half reactions involved during ammonia oxidation and autotrophic denitrification written as reduction processes $\left(\mathrm{E}_{\mathrm{H}}\right.$ was calculated considering $[\mathrm{Ox}] /[\mathrm{Red}]=1[15]$ ).

\begin{tabular}{|c|c|c|}
\hline Process & Half reaction & $\mathrm{E}_{\mathrm{H}}(\mathrm{V}) *$ \\
\hline \multicolumn{3}{|c|}{ Partial nitrification } \\
\hline & $1 / 4 \mathrm{O}_{2}+\mathrm{H}^{+}+\mathrm{e}^{-} \longrightarrow 1 / 2 \mathrm{H}_{2} \mathrm{O}$ & $1.23-\frac{2.303 \cdot R T}{F} \cdot p H$ \\
\hline & $1 / 8 \mathrm{~N}_{2} \mathrm{O}+5 / 4 \mathrm{H}^{+}+\mathrm{e}^{-} \longrightarrow 1 / 8 \mathrm{H}_{2} \mathrm{O}+1 / 4 \mathrm{NH}_{4}^{+}$ & $2.04-\frac{2.303 \cdot R T}{F} \cdot \frac{5}{4} \cdot p H$ \\
\hline & $1 / 6 \mathrm{NO}_{2}{ }^{-}+4 / 3 \mathrm{H}^{+}+\mathrm{e}^{-} \longrightarrow 1 / 6 \mathrm{NH}_{4}{ }^{+}+1 / 3 \mathrm{H}_{2} \mathrm{O}$ & $0.89-\frac{2.303 \cdot R T}{F} \cdot \frac{4}{3} \cdot p H$ \\
\hline \multicolumn{3}{|c|}{ Autotrophic denitrification } \\
\hline & $1 / 5 \mathrm{NO}_{3}^{-}+6 / 5 \mathrm{H}^{+}+\mathrm{e}^{-} \longrightarrow 1 / 10 \mathrm{~N}_{2}+3 / 5 \mathrm{H}_{2} \mathrm{O}$ & $1.25-\frac{2.303 \cdot R T}{F} \cdot \frac{6}{5} \cdot p H$ \\
\hline & $1 / 3 \mathrm{NO}_{2}^{-}+4 / 3 \mathrm{H}^{+}+\mathrm{e}^{-} \longrightarrow 1 / 6 \mathrm{~N}_{2}+2 / 3 \mathrm{H}_{2} \mathrm{O}$ & $0.42-\frac{2.303 \cdot R T}{F} \cdot \frac{4}{3} \cdot p H$ \\
\hline & $1 / 8 \mathrm{SO}_{4}^{-2}+9 / 8 \mathrm{H}^{+}+\mathrm{e}^{-} \longrightarrow 1 / 8 \mathrm{HS}^{-}+1 / 2 \mathrm{H}_{2} \mathrm{O}$ & $0.25-\frac{2.303 \cdot R T}{F} \cdot \frac{9}{8} \cdot p H$ \\
\hline & $1 / 2 \mathrm{~S}+1 / 2 \mathrm{H}^{+}+\mathrm{e}^{-} \longrightarrow 1 / 2 \mathrm{HS}^{-}$ & $-0.11-\frac{2.303 \cdot R T}{F} \cdot \frac{1}{2} \cdot p H$ \\
\hline
\end{tabular}

$* \mathrm{~F}$ is the Faraday constant $(96,500 \mathrm{C} / \mathrm{mol})$

of ammonia oxidation, $\mathrm{NH}_{4}{ }^{+}$was selected as the electron reference level from the redox ladder while bisulphide (HS ${ }^{-}$) was chosen for autotrophic denitrification, since these are the main species at the analyzed $\mathrm{pH}$ conditions. Then, the OXC was calculated according to (2) and (3) for ammonia oxidation and denitrification processes, respectively:

OXC (equivalents/L)

$$
=4 \cdot[\mathrm{DO}] / 16000+6 \cdot\left[\mathrm{NO}_{2}{ }^{-}-\mathrm{N}\right] / 14000
$$

OXC (equivalents/L)

$$
\begin{aligned}
= & 5 \cdot\left[\mathrm{NO}_{3}{ }^{-}-\mathrm{N}\right] / 14000+3 \cdot\left[\mathrm{NO}_{2}{ }^{-} \mathrm{-N}\right] / 14000+8 \\
& \cdot\left[\mathrm{SO}_{4}{ }^{-2}-\mathrm{S}\right] / 32000
\end{aligned}
$$

where $[\mathrm{DO}]$ is the dissolved oxygen concentration $\left(\mathrm{mg} \mathrm{O}_{2} / \mathrm{L}\right)$, $\left[\mathrm{NO}_{2}{ }^{-}-\mathrm{N}\right]$ is the nitrogen concentration as nitrite $\left(\mathrm{mg} \mathrm{NO}_{2}{ }^{-}\right.$ $\mathrm{N} / \mathrm{L}),\left[\mathrm{NO}_{3}{ }^{-}-\mathrm{N}\right]$ is the nitrogen concentration as nitrate 
TABLE 4: $\mathrm{E}_{\mathrm{H}}$ calculation of the redox half-reactions involved during ammonia oxidation and autotrophic denitrification processes under the operating conditions of each studied stage.

\begin{tabular}{|c|c|c|c|}
\hline Nitrification & $\begin{array}{c}\mathrm{N}_{2} \mathrm{O} \text { reduction to } \mathrm{NH}_{4}^{+} \\
(\mathrm{V})\end{array}$ & $\begin{array}{c}\mathrm{O}_{2} \text { reduction to } \mathrm{H}_{2} \mathrm{O} \\
(\mathrm{V})\end{array}$ & $\begin{array}{c}\mathrm{NO}_{2}{ }^{-} \text {reduction to } \mathrm{NH}_{4}{ }^{+} \\
(\mathrm{V})\end{array}$ \\
\hline Stage 1 & 1.49 & 0.79 & 0.30 \\
\hline Stage 2 & 1.49 & 0.79 & 0.30 \\
\hline Stage 3 & 1.49 & 0.79 & 0.30 \\
\hline Stage 4 & 1.49 & 0.79 & 0.30 \\
\hline Stage 5 & 1.49 & 0.79 & 0.30 \\
\hline Stage 6 & 1.49 & 0.79 & 0.30 \\
\hline Stage 7 & 1.49 & 0.79 & 0.30 \\
\hline Stage 8 & 1.49 & 0.79 & 0.30 \\
\hline Stage 9 & 1.49 & 0.79 & 0.30 \\
\hline Stage 10 & 1.49 & 0.79 & 0.30 \\
\hline Stage 11 & 1.49 & 0.79 & 0.30 \\
\hline Stage 12 & 1.49 & 0.79 & 0.30 \\
\hline
\end{tabular}

\begin{tabular}{lcccc}
\hline Autotrophic denitrification & $\mathrm{NO}_{3}{ }^{-}$reduction to $\mathrm{N}_{2}$ & $\mathrm{NO}_{2}{ }^{-}$reduction to $\mathrm{N}_{2}$ & $\mathrm{SO}_{4}{ }^{-2}$ reduction to $\mathrm{HS}^{-}$ & $\begin{array}{c}\mathrm{S}^{2} \text { reduction to } \mathrm{HS}^{-} \\
(\mathrm{V})\end{array}$ \\
\hline Stage 1 & 0.70 & -0.19 & -0.27 & -0.34 \\
Stage 2 & 0.68 & -0.21 & -0.28 & -0.35 \\
Stage 3 & 0.64 & -0.26 & -0.32 & -0.36 \\
Stage 4 & 0.59 & -0.31 & -0.37 & -0.38 \\
Stage 5 & 0.72 & -0.17 & -0.25 & -0.33 \\
Stage 6 & 0.67 & -0.23 & -0.29 & -0.35 \\
Stage 7 & 0.66 & -0.24 & -0.31 & -0.36 \\
Stage 8 & 0.70 & -0.19 & -0.26 & -0.34 \\
Stage 9 & 0.70 & -0.19 & -0.26 & -0.34 \\
\hline
\end{tabular}

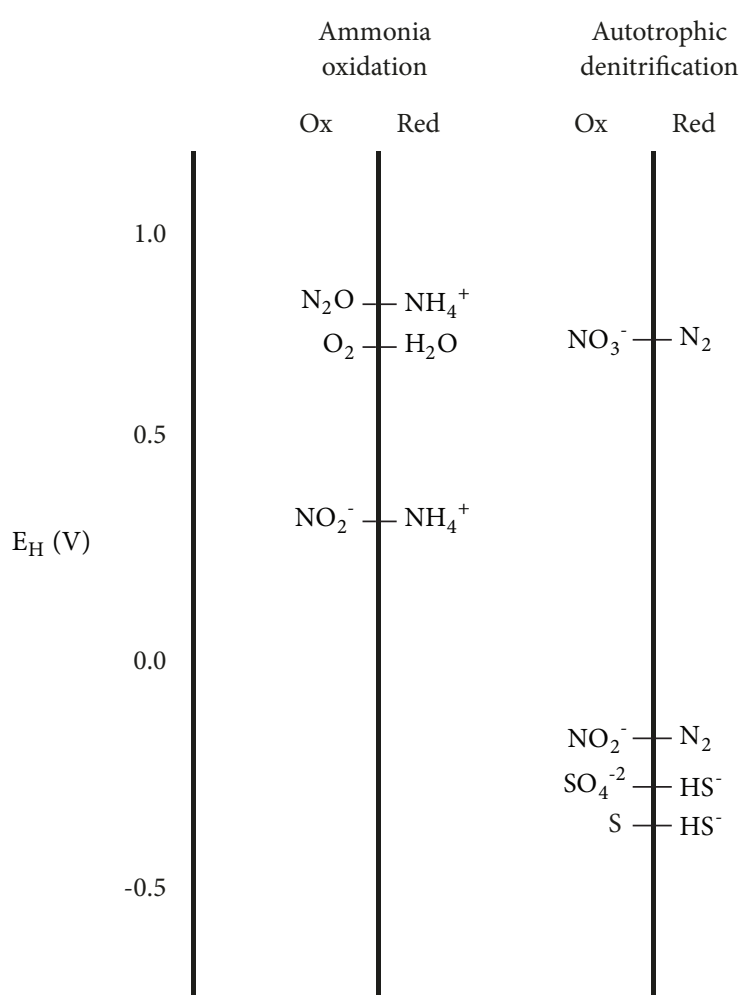

FIGURE 1: "Redox ladder" for the ammonia oxidation and autotrophic denitrification processes (adapted from Scott and Morgan [17]). 


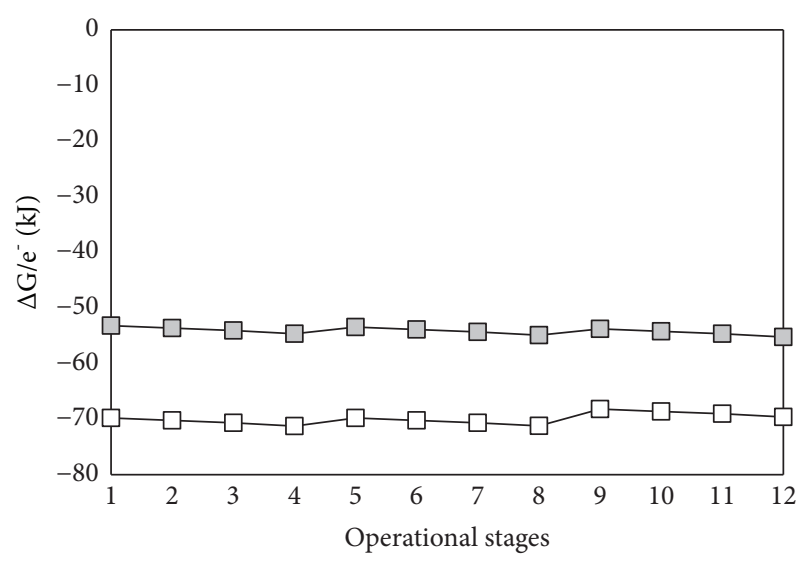

(a)

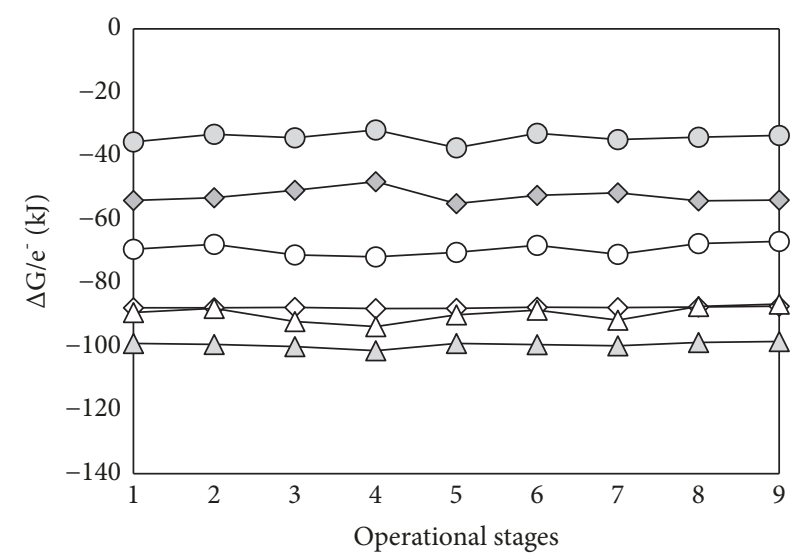

(b)

FIGURE 2: Gibbs free energy (kJ) per electron mol transferred under the conditions of the different operational stages: (a) ammonia oxidation: - reaction (i); $\square$ reaction (ii) and (b) autotrophic denitrification: $\diamond$ reaction (iii); $\diamond$ reaction (iv); $\bullet$ reaction (v); o reaction (vi); $\Delta$ reaction (vii); $\Delta$ reaction (viii)). All reactions are described in Table 2.

( $\left.\mathrm{mg} \mathrm{NO}_{3}{ }^{-}-\mathrm{N} / \mathrm{L}\right)$, and $\left[\mathrm{SO}_{4}{ }^{-2}-\mathrm{S}\right]$ is the sulphur concentration as sulphate $\left(\mathrm{mg} \mathrm{SO}_{4}{ }^{-2}-\mathrm{S} / \mathrm{L}\right)$.

In order to obtain a specific rate of production intermediate compounds for each operational condition analyzed, the production of $\mathrm{NO}_{2}{ }^{-}, \mathrm{N}_{2} \mathrm{O}$, and $\mathrm{S}^{0}$ was normalized using the measured biomass as volatile suspended solids (VSS) $[9,12]$.

2.3. Statistical Analyses. Simple linear regression analysis between the calculated OXC (explanatory variable) and the measured production of intermediate species (dependent variable) was performed using XLSTAT $^{\circledR}$ software (Addinsoft, France). In order to evaluate the fitting of the regression models, regression characteristic ( $p$-values and $\mathrm{R}^{2}$ ) and standardized residuals were studied. The confidence and prediction intervals were calculated by using the $F$ distribution and analysis of variance (ANOVA) test. $P$-value $\leq 0.05$ was considered significant. A 95\% prediction interval was determined, being the range in which one can expect any individual value to fall into $95 \%$ of the time.

\section{Results and Discussion}

3.1. Gibbs Free Energy. The calculation of the Gibbs free energy shows that, for all of the operational conditions tested in the nitrification experiments, oxidation of ammonia to nitrous oxide provides higher energy per mol of $\mathrm{e}^{-}$ transferred to microorganisms than its oxidation to nitrite (Figure 2(a)). This fact could justify that nitrous oxide production was always detected although the predominant product was always nitrite (Table 1 ). The literature reports that $\mathrm{N}_{2} \mathrm{O}$ could be also generated during heterotrophic denitrification [9]. However, in this process, the energy available in the $\mathrm{NO}_{3}{ }^{-} / \mathrm{NO}_{2}{ }^{-}$reduction to $\mathrm{N}_{2}$ was higher compared with the reduction to $\mathrm{N}_{2} \mathrm{O}$ [18] and, therefore, the Gibbs free energy does not explain nitrous oxide generation. The generation of $\mathrm{N}_{2} \mathrm{O}$ during heterotrophic denitrification is generally associated to the effect of environmental conditions on the different nitrogen oxide reductases involved in the four reductive steps of complete denitrification. Denitrification enzymes receive their electrons from a common source (i.e., the ubiquinone/ubiquinol pool of the respiratory electron transport chain [19]), and limitations in the electron supply rate or in substrate availability can result in electron competition among these enzymes and accumulation of nitrogen oxide intermediates [20]. Also, it has been shown that $\mathrm{pH}$ affects the electron donor oxidation rate supplying electrons and the nitrogen reductases activity [21]. In the case of ammonia oxidation (such as the observed in the studied experiments), it has been shown that the production of $\mathrm{N}_{2} \mathrm{O}$ can be related to an imbalanced metabolic activity and enzymatic regulation of $\mathrm{AOB}$, especially under cyclic transitions in DO concentrations, or to chemical decomposition and oxidation of intermediate compounds [8]. Therefore, the key factors controlling intermediate compounds formation such as $\mathrm{N}_{2} \mathrm{O}$ during nitrification may not only be energy availability but also environmental conditions.

For the autotrophic denitrification experiments, according to the calculated Gibbs free energy (Figure 2(b)), the most thermodynamically favorable reactions are those where elemental sulfur is consumed (reactions (vii) and (viii) of Table 2), which would explain the consumption of this compound observed during the operational stages 6,8 , and 9 (Table 1). Nevertheless, according to the free energy calculations the least favorable reactions are those where elemental sulfur is the end product (reaction (iii) and (v) of Table 2). This fact that does not agree with the experimental results found during stages $2,3,4$, and 7 where $S^{0}$ accumulation was observed. On the other hand, despite the fact that the reduction of nitrate into nitrogen gas provides more energy than its reduction to nitrite (Figure $2(\mathrm{~b})$ ), $\mathrm{NO}_{2}{ }^{-}$was detected during almost all operational stages of autotrophic denitrification process (Table 1). In sulfur-based autotrophic denitrification systems the formation of intermediate compounds has been related to the feeding $\mathrm{S} / \mathrm{N}$ ratio and the operational conditions $[9,16]$, which are not evaluated using free energy analyses. 


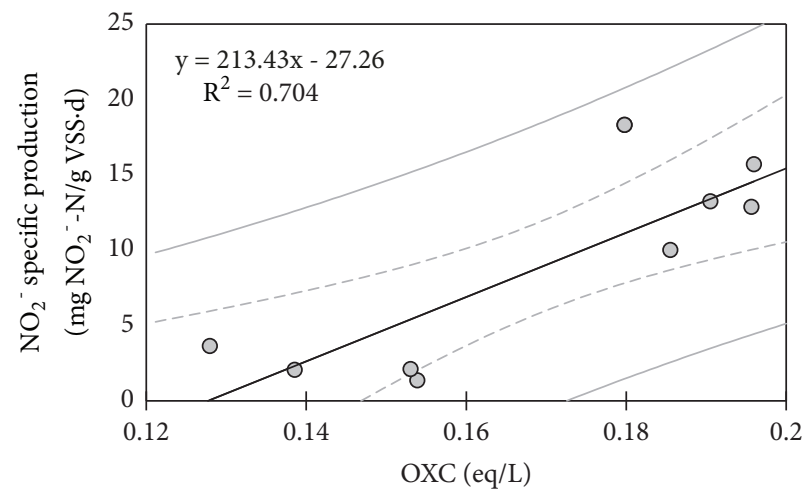

(a)

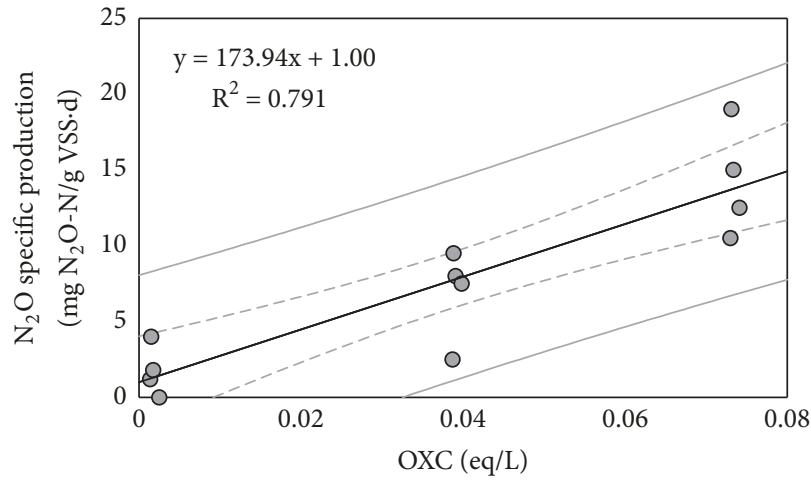

(b)

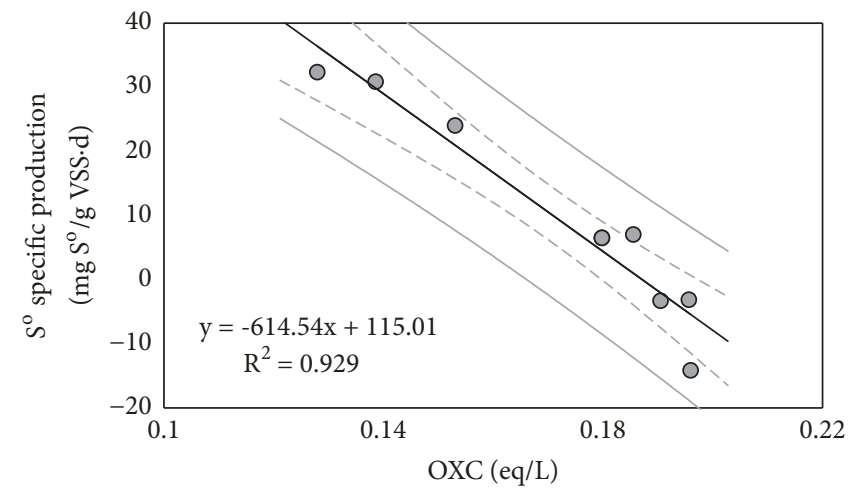

(c)

FIGURE 3: Regression lines between the specific production of nitrous oxide (a) and elemental sulphur (b) and nitrite (c) for each operational stage and the oxidative capacity of the bulk liquid. Dashed grey lines represent the $95 \%$ confidence interval, and solid grey lines represent the $95 \%$ prediction interval (in the case of elemental sulphur, negative production values indicate an overall consumption of the $S^{\circ}$ accumulated in the system).

According to Seto and Iwasa [22], the behavior of chemotrophic microorganisms under anaerobic conditions is affected by the low level of energy available from redox reactions and, therefore, it would be expected that Gibbs free energy per electron mol transferred $\left(\Delta \mathrm{G} / \mathrm{e}^{-}\right)$was an appropriate parameter to predict the accumulation of intermediate products at least for autotrophic denitrification. Nevertheless, the discrepancies between experimental data and those obtained by the theoretical calculations indicate the opposite.

3.2. Oxidative Capacity. Analyses by linear regression showed significance and a strong to very strong relationship between the OXC of the bulk liquid and the production of intermediate compounds, in nitrification and autotrophic denitrification processes (Figure 3). In the case of nitrification, $\mathrm{N}_{2} \mathrm{O}$ specific production increases with the increase of the OXC of the bulk liquid (Figure $3(a), R^{2}=$ $0.704, p<0.05)$. That is, $\mathrm{N}_{2} \mathrm{O}$ formation is promoted by both high DO and nitrite concentration. This agrees with the results of $\mathrm{He}$ et al. [23] who observed that $\mathrm{N}_{2} \mathrm{O}$ production was favored by high redox potential inside nitrifying biofilms. However, some studies reported that $\mathrm{N}_{2} \mathrm{O}$ formation decreased when the system was operated at high DO levels [24]. This cannot be attributed to the own effect of the dissolved oxygen but to the decrease of nitrite accumulation during the operation at high DO concentrations. In fact, Castro-Barros et al. [25] found an increase in the production of nitrous oxide at higher DO concentrations when nitrite was added to a nitrifying system. Moreover, high oxidative capacity and redox potential values are already reported in the literature as the most important parameters responsible for $\mathrm{N}_{2} \mathrm{O}$ production during nitrification in soils [4].

In the case of autotrophic denitrification, sulphur generation seems to be promoted by less oxidative environments while the opposite trend is observed for nitrite (Figures $3(\mathrm{~b})$ and $3(\mathrm{c}), \mathrm{R}^{2}=0.791$ and $\left.0.929, p<0.05\right)$. Generally, the formation of both intermediate compounds is related to the feeding S/N ratio: an excess of electron donor causes the accumulation of elemental sulphur while an excess of electron acceptor leads to the generation of nitrite $[13,14]$. Nevertheless, this is not a valid criterion to predict the formation of intermediates since some studies showed that $S^{0}$ can be accumulated even under sulphide limitation conditions [10, 12 ] and, on the other hand, nitrite production was observed in the systems operated with an excess of sulphide [26]. Accumulation of $S^{\circ}$ during autotrophic denitrification is also related to high $\mathrm{pH}$ values $(>8.5)$ [12]. This could be attributed to the effect of the $\mathrm{pH}$ on the redox state, probably due to a 
shift in the $\mathrm{H}_{2} \mathrm{~S} / \mathrm{HS}^{-} / \mathrm{S}^{2-}$ equilibrium, since higher $\mathrm{pH}$ values lead to lower redox potentials (lower oxidative capacity). This agrees with the results obtained in sulfide-oxidizing bioreactors showing that the formation of elemental sulfur is optimal at low redox potentials [27]. A similar tendency has also been observed during the aerobic oxidation of sulphide: the yield of $S^{\circ}$ increases as the DO concentration decreases due to the decrease of the redox potential [28].

The redox potential corresponds to the activity of the electrons present in the bulk liquid that influences the $\mathrm{NAD}^{+} / \mathrm{NADH}$ ratio within cells. This ratio controls gene expression and enzyme synthesis for the overall cell metabolic activities [29]. Therefore, it is reasonable to think that the redox potential value inside bioreactors can affect the metabolite generation and, therefore, the spectrum of products obtained depending on the extracellular redox conditions. In fact, electrofermentation is a novel technique that is being used to change the overall performance in mixedculture fermentations, by altering both microbial community structure and metabolic patterns [30]. Also, electrochemical control of the redox potential in mixed culture bioreactors has been shown to regulate microbial metabolites production [31].

In summary, the results show that there is good agreement between calculated $\mathrm{OXC}$ values and the specific rate of production of nitrous oxide, elemental sulfur, and nitrite, as intermediate compounds in the analyzed nitrification and autotrophic denitrification systems. This suggests that the OXC calculation can be used to assess and predict the generation of these intermediate compounds.

\section{Conclusions}

The value of the Gibbs free energy calculated for the evaluated operational conditions cannot be used in order to predict the formation of nitrous oxide, elemental sulphur, and nitrite during nitrification and autotrophic denitrification processes. Nevertheless, the oxidative capacity of the bulk liquid appears as a useful tool to predict the accumulation of these intermediates. The oxidative capacity is a parameter simple to calculate and may provide a valuable starting point for the evaluation of the accumulation of undesirable intermediate compounds in wastewater treatment systems.

\section{Data Availability}

The data used to support the findings of this study are included within the article.

\section{Conflicts of Interest}

The authors declare that they have no conflicts of interest.

\section{Acknowledgments}

This work was funded by the Chilean Government through the project FONDECYT 1180650, CONICYT/ FONDAP/15130015 and CONICYT PIA/BASAL FB0002, and by the Spanish Government through TREASURE [CTQ201783225-C2-1-R] and GRANDSEA [CTM2014-55397-JIN] projects. The authors from Universidade de Santiago de Compostela belong to CRETUS [AGRUP2015/02] and the Galician Competitive Research Group [GRC ED431C 2017/ 29]. All these programs are cofunded by FEDER.

\section{References}

[1] B. Halling-Sørensen, "Biological nitrification and denitrification," Studies in Environmental Science, vol. 54, pp. 43-53, 1993.

[2] Y.-H. Ahn, "Sustainable nitrogen elimination biotechnologies: a review," Process Biochemistry, vol. 41, no. 8, pp. 1709-1721, 2006.

[3] R. Sierra-Alvarez, R. Beristain-Cardoso, M. Salazar, J. Gómez, E. Razo-Flores, and J. A. Field, "Chemolithotrophic denitrification with elemental sulfur for groundwater treatment," Water Research, vol. 41, no. 6, pp. 1253-1262, 2007.

[4] B. Wang, J. Zhao, Z. Guo, J. Ma, H. Xu, and Z. Jia, "Differential contributions of ammonia oxidizers and nitrite oxidizers to nitrification in four paddy soils," The ISME Journal, vol. 9, no. 5, pp. 1062-1075, 2015.

[5] M. Shao, T. Zhang, and H. H. Fang, "Sulfur-driven autotrophic denitrification: diversity, biochemistry, and engineering applications," Applied Microbiology and Biotechnology, vol. 88, no. 5, pp. 1027-1042, 2010.

[6] G. Claus and H. Kutzner, "Physiology and kinetics of autotrophic denitrification by Thiobacillus denitrificans," Applied Microbiology and Biotechnology, vol. 22, no. 4, pp. 283-288, 1985.

[7] S. Dasgupta, S. Wu, and R. Goel, "Coupling autotrophic denitrification with partial nitritation-anammox (PNA) for efficient total inorganic nitrogen removal," Bioresource Technology, vol. 243, pp. 700-707, 2017.

[8] P. Wunderlin, J. Mohn, A. Joss, L. Emmenegger, and H. Siegrist, "Mechanisms of $\mathrm{N}_{2} \mathrm{O}$ production in biological wastewater treatment under nitrifying and denitrifying conditions," Water Research, vol. 46, no. 4, pp. 1027-1037, 2012.

[9] J. L. Campos, B. Arrojo, J. R. Vázquez-Padín, A. MosqueraCorral, and R. Méndez, " $\mathrm{N}_{2} \mathrm{O}$ production by nitrifying biomass under anoxic and aerobic conditions," Applied Biochemistry and Biotechnology, vol. 152, no. 2, pp. 189-198, 2009.

[10] C. Liu, W. Li, X. Li et al., "Nitrite accumulation in continuousflow partial autotrophic denitrification reactor using sulfide as electron donor," Bioresource Technology, vol. 243, pp. 1237-1240, 2017.

[11] B. Krishnakumar and V. Manilal, "Bacterial oxidation of sulphide under denitrifying conditions," Biotechnology Letters, vol. 21, no. 5, pp. 437-440, 1999.

[12] C. Fajardo, A. Mosquera-Corral, J. Campos, and R. Méndez, "Autotrophic denitrification with sulphide in a sequencing batch reactor," Journal of Environmental Management, vol. 113, pp. 552-556, 2012.

[13] R. Yamamoto-Ikemoto, T. Komori, M. Nomura, Y. Ide, and T. Matsukami, "Nitrogen removal from hydroponic culture wastewater by autotrophic denitrification using thiosulfate," Water Science and Technology, vol. 42, no. 3-4, pp. 369-376, 2000.

[14] I. Manconi, A. Carucci, and P. Lens, "Combined removal of sulfur compounds and nitrate by autotrophic denitrification in bioaugmented activated sludge system," Biotechnology and Bioengineering, vol. 98, no. 3, pp. 551-560, 2007. 
[15] P. Dolejs, L. Paclík, J. Maca, D. Pokorna, J. Zabranska, and J. Bartacek, "Effect of S/N ratio on sulfide removal by autotrophic denitrification," Applied Microbiology and Biotechnology, vol. 99, no. 5, pp. 2383-2392, 2015.

[16] C. Liu, D. Zhao, L. Yan, A. Wang, Y. Gu, and D. Lee, "Elemental sulfur formation and nitrogen removal from wastewaters by autotrophic denitrifiers and anammox bacteria," Bioresource Technology, vol. 191, pp. 332-336, 2015.

[17] M. J. Scott and J. J. Morgan, "Energetics and conservative properties of redox systems," in Chemical Modeling of Aqueous Systems II, vol. 416 of ACS Symposium Series, pp. 368-378, American Chemical Society, Washington, DC, 1990.

[18] R. González-Cabaleiro, I. D. Ofițeru, J. M. Lema, and J. Rodríguez, "Microbial catabolic activities are naturally selected by metabolic energy harvest rate," The ISME Journal, vol. 9, no. 12, pp. 2630-2641, 2015.

[19] D. Richardson, H. Felgate, N. Watmough, A. Thomson, and E. Baggs, "Mitigating release of the potent greenhouse gas N2O from the nitrogen cycle - could enzymic regulation hold the key?" Trends in Biotechnology, vol. 27, no. 7, pp. 388-397, 2009.

[20] Y. Pan, B. Ni, P. L. Bond, L. Ye, and Z. Yuan, "Electron competition among nitrogen oxides reduction during methanolutilizing denitrification in wastewater treatment," Water Research, vol. 47, no. 10, pp. 3273-3281, 2013.

[21] Y. Pan, L. Ye, B. Ni, and Z. Yuan, "Effect of $\mathrm{pH}$ on $\mathrm{N} 2 \mathrm{O}$ reduction and accumulation during denitrification by methanol utilizing denitrifiers," Water Research, vol. 46, no. 15, pp. 4832-4840, 2012.

[22] M. Seto and Y. Iwasa, "Population dynamics of chemotrophs in anaerobic conditions where the metabolic energy acquisition per redox reaction is limited," Journal of Theoretical Biology, vol. 467, pp. 164-173, 2019.

[23] Q. He, Y. Zhu, L. Fan, H. Ai, X. Huangfu, and M. Chen, "Effects of $\mathrm{C} / \mathrm{N}$ ratio on nitrous oxide production from nitrification in a laboratory-scale biological aerated filter reactor," Water Science and Technology, vol. 75, no. 6, pp. 1270-1280, 2017.

[24] L. Peng, B. Ni, L. Ye, and Z. Yuan, "The combined effect of dissolved oxygen and nitrite on $\mathrm{N} 2 \mathrm{O}$ production by ammonia oxidizing bacteria in an enriched nitrifying sludge," Water Research, vol. 73, pp. 29-36, 2015.

[25] C. M. Castro-Barros, A. Rodríguez-Caballero, E. I. P. Volcke, and M. Pijuan, "Effect of nitrite on the $\mathrm{N}_{2} \mathrm{O}$ and $\mathrm{NO}$ production on the nitrification of low-strength ammonium wastewater," Chemical Engineering Journal, vol. 287, pp. 269-276, 2016.

[26] W. Yang, H. Lu, S. K. Khanal, Q. Zhao, L. Meng, and G. Chen, "Granulation of sulfur-oxidizing bacteria for autotrophic denitrification," Water Research, vol. 104, pp. 507-519, 2016.

[27] A. J. H. Janssen, S. Meijer, J. Bontsema, and G. Lettinga, "Application of the redox potential for controlling a sulfide oxidizing bioreactor," Biotechnology and Bioengineering, vol. 60, no. 2, pp. 147-155, 1998.

[28] B. Krishnakumar, S. Majumdar, V. B. Manilal, and A. Haridas, "Treatment of sulphide containing wastewater with sulphur recovery in a novel reverse fluidized loop reactor (RFLR)," Water Research, vol. 39, no. 4, pp. 639-647, 2005.

[29] C. Liu, C. Xue, Y. Lin, and F. Bai, "Redox potential control and applications in microaerobic and anaerobic fermentations," Biotechnology Advances, vol. 31, no. 2, pp. 257-265, 2013.

[30] R. Moscoviz, E. Trably, and N. Bernet, "Electro-fermentation triggering population selection in mixed-culture glycerol fermentation," Microbial Biotechnology, vol. 11, no. 1, pp. 74-83, 2018.
[31] Y. Jiang, L. Lu, H. Wang et al., "Electrochemical control of redox potential arrests methanogenesis and regulates products in mixed culture electro-fermentation," ACS Sustainable Chemistry \& Engineering, vol. 6, no. 7, pp. 8650-8658, 2018. 


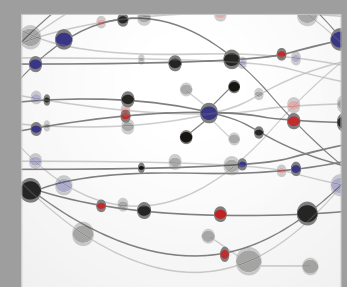

The Scientific World Journal
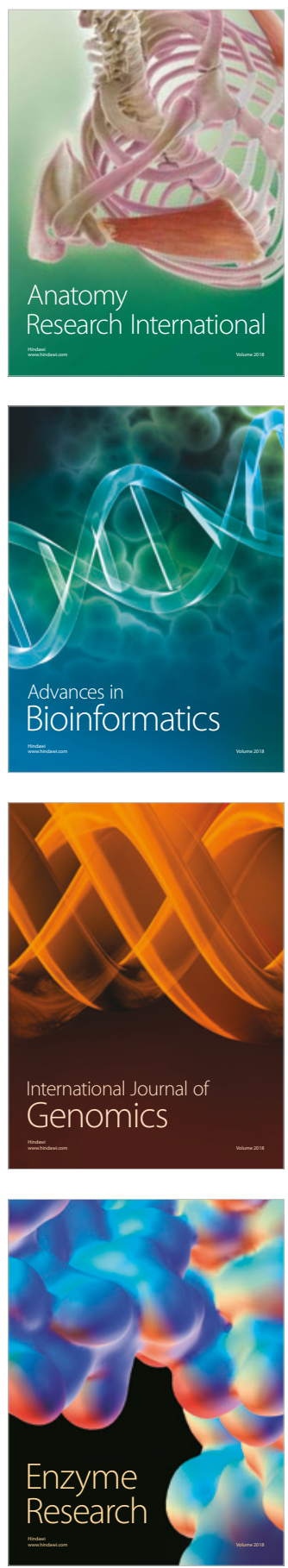
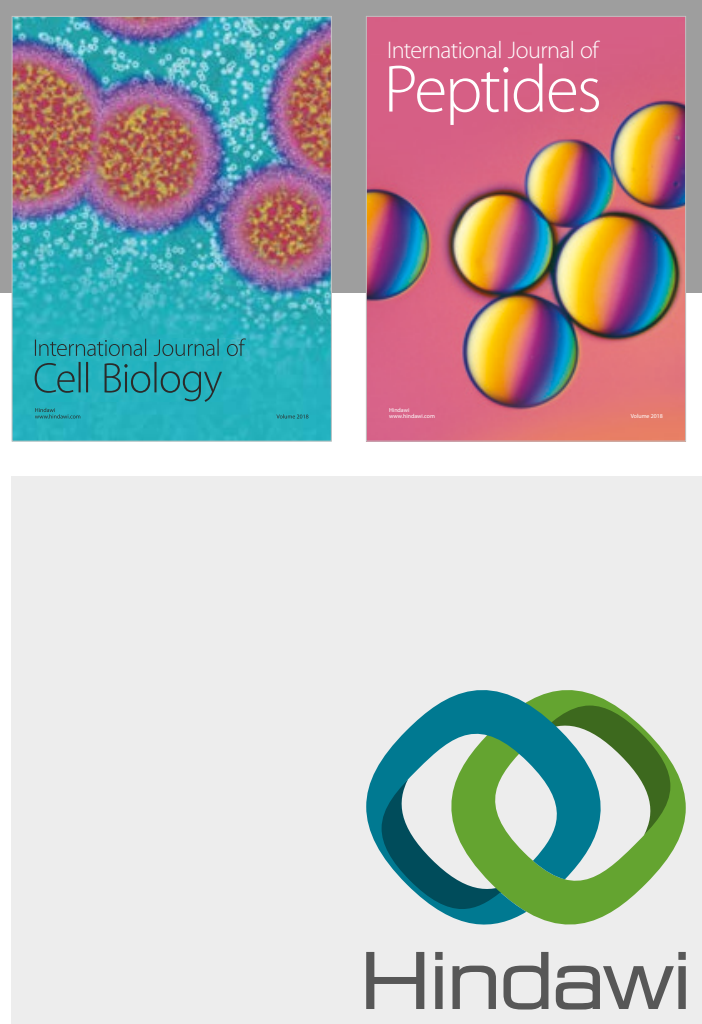

Submit your manuscripts at

www.hindawi.com
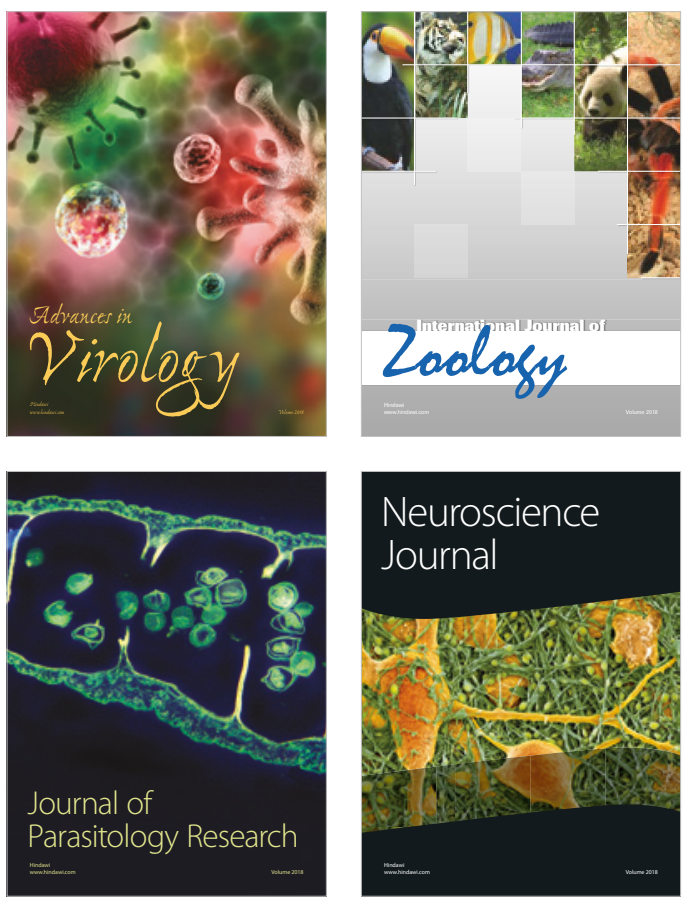
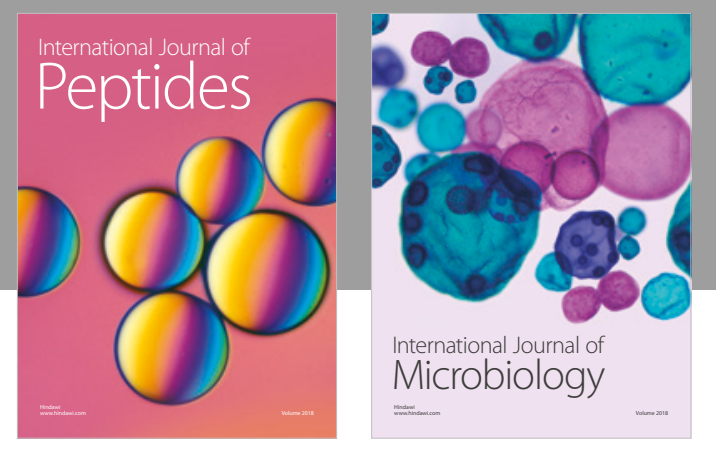

nternational Journal of Microbiology
Journal of
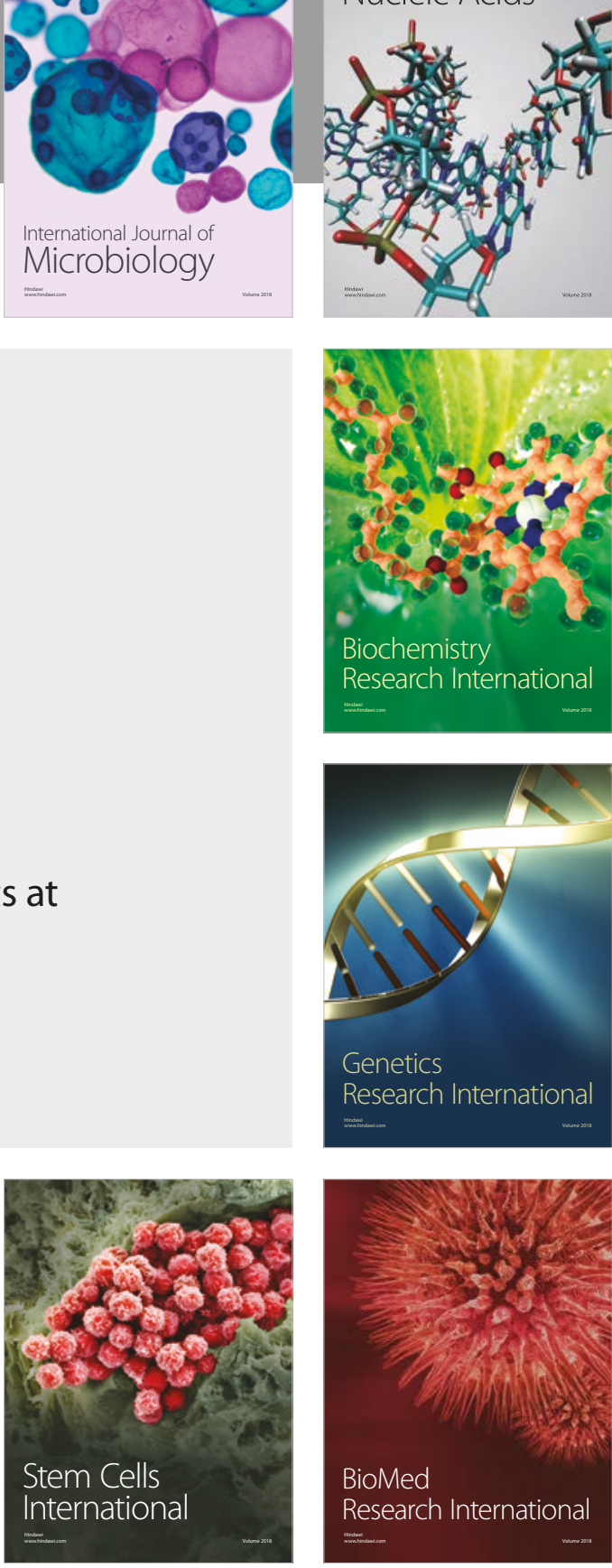
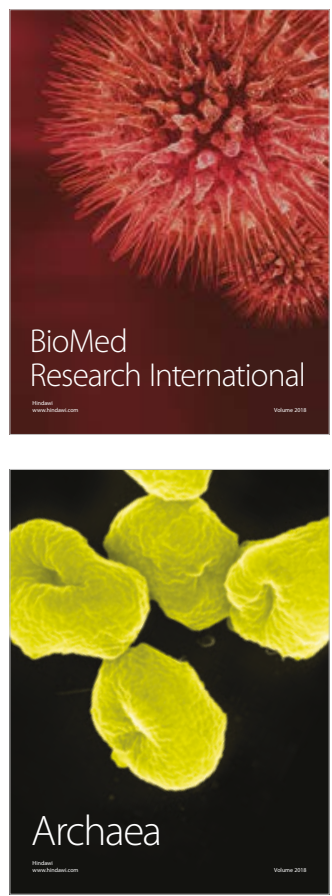